\title{
Calf rennet production and its performance optimization
}

\author{
Asfawosen Mamo and Nedumaran Balasubramanian* \\ Chemical Engineering Program, School of Mechanical, Chemical and Materials Engineering, Adama Science and \\ Technology University, POBox 1888, Adama, Ethiopia \\ *Corresponding author. E-mail: nedumaran_b@yahoo.co.in
}

Received: August 26, 2017; Revised received: October 10, 2017; Accepted: January 31, 2018

\begin{abstract}
Milk clotting enzymes are one of the most significant cheese making raw materials impacting and regulating milk coagulation activity. Calf rennet is one of the enzymes which extracted from suckling calf abomasum. The rennet extracted was optimized for its clotting time $\mathrm{t}(\mathrm{s})$ by varying three levels of temperature $\left(30,35\right.$ and $\left.40^{\circ} \mathrm{C}\right), \mathrm{pH}$ $(4,5$ and 6$)$ and $\mathrm{CaCl}_{2}$ concentration $(0.1,0.2$ and $0.3 \mathrm{gm} / 500 \mathrm{ml}$ of milk) using response surface method (RSM) and also its milk clotting activity (MCA) was determined. Based on the optimized result, temperature $39.13^{\circ} \mathrm{C}, \mathrm{pH} 4$ and $\mathrm{CaCl}_{2}$ concentration of $0.21 \mathrm{gm} / 500 \mathrm{ml}$ had resulted minimum clotting time of $91.27 \mathrm{~s}$. Using this minimum clotting time, the strength was found to be $1: 13148$, establishing the fact that the calf rennet is the best natural coagulant of milk.
\end{abstract}

Keywords: Abomasum, Calf rennet, Clotting time, Response surface method.

\section{INTRODUCTION}

The products obtained from Cows are well known to mankind, such as Gorochan (Sailaja et al., 2017), known as Gorojanam (Sanskrit, Tamil) is one of the products of cholelithiasis in the gall bladder and ducts of cow and bull which is laxative, antispasmodic, cholagogue and cooling and used as traditional Indian ayurvedic medicine in treatment of cholera, convulsions and hysteria in the range of $50-250(\mu \mathrm{g} / \mathrm{ml})$. Similarly Rennet is very important in the stomach of young mammals as they digest their mothers' milk. The active enzyme in rennet is called chymosin or rennin (EC 3.4.23.4) but there are also other important enzymes in it including pepsin and lipase. High pepsin content results in bitterness of the product (Visser et al., 1987, Hubble and Mann, 1984, Libouga, 2004). The amino acid sequence of chymosin with summary of the data from which the sequence was derived have been presented (Bent et al., 1979).

The dairy calf is a monogastric or simple stomached animal, whose digestive system is underdeveloped until two weeks from birth. The abomasum is the only stomach compartment actively involved in digestion. As a result, only liquid feed can be utilized effectively by pre-ruminant calves a few days old. As the calf begins to eat dry feeds, particularly grains containing readily fermentable carbohydrates, the rumen takes on a more important role. The stomach compartments grow and change as the calf develops into a ruminant animal. The fascinating differences between calves and mature ruminants create unique nutritional needs for pre-weaned calves (Moran, 2005).

Milk coagulation properties (MCP) are an important aspect in assessing cheese-making ability. Several studies showed that favorable conditions of milk reactivity with rennet, curd formation rate, and curd strength, as well as curd synthesis, have a positive effect on the entire cheese-making process and subsequently on the ripening of cheese. Moreover, MCP were found to be heritable. Selecting for high casein content, milk acidity, and low somatic cell count might be an indirect way to improve MCP without reducing milk yield and quality traits (Cassandro et al., 2008).

MCP is of great importance as it significantly influence cheese yield and quality. Milk clotting enzymes are one of the most significant cheese making raw materials impacting and regulating milk coagulation activity. Use of calf rennet as a milk clotting enzyme in the manufacturing of cheese has been predominant in the industry for years. Rennet is a complex of enzymes produced in any mammalian stomach. It contains many enzymes, including a proteolytic enzyme (protease) that coagulates the milk, causing it to separate into solids (curds) and liquid (whey) (Green et al., 1985). Short chain of free fatty acids produced by lipolytic enzymes contained in rennet extracted from a crude abomasum of mammals attribute to characteristic flavor of cheese (Moghaddam et al., 2008, Sengul et al., 2014). Composition, nitrogen fractions, $\alpha_{\mathrm{s} 1}-$ casein and $\beta$-casein degradation and certain textural properties of the cheese during ripening are associated with the type of coagulants used. (Sengul et al., 2014). Proteolytic degradation of casein can release active 
functioan properties during cheese ripening, where the texture, sensory and organoleptic characteristics are developed (Katarzyna et al., 2017).

Rennet is an extract from the fourth stomach (abomasum or rennet-bag) of ruminant animals, principally calves, with the capability of clotting milk by enzymatic action (Green 1985). The stomachs of lambs, kids, pigs and hares have been used to extract rennet but the principal species used is calf (National Dairy Council, 1992). The enzymes extracted from abomasums are chymosin and pepsin, and these are produced in glandular cells in the mucosa. Animal rennets are secreted from the stomach mucosa as inactive proteolytic enzymes that can easily be extracted by maceration with water, weak brine or a buffer solution. A preservative sodium benzoate, $(0.1 \%$ ) (Libouga, 2004) is normally added at this stage to prevent microbial growth during the next stages of production, involving filtration and acidification to activate the proteolytic enzymes. After neutralisation to $\mathrm{pH} 5.5$ and a second filtration to clarify the extract, the preparation is standardised to the 'advertised' milk clotting activity, sterile-filtered and packaged as a liquid enzyme product to be transported and stored refrigerated. Animal rennets are not purified products, but contain whatever enzymes were secreted by the mucosal tissues available (Whitehurst and Law, 2002).

Milk clotting is a resultant outcome involving both enzymatic and non-enzymatic reactions, where internal variants among milk samples are likely to result in difference in clotting time, which further makes it difficult to establish a standard milk substrate for the measurement of rennet activity (Cassandro et al., 2008). O'Callaghan et al. (2002) reviewed several systems (optical, thermal, mechanical, and vibrational) for monitoring milk coagulation during cheese making. The sequence of reaction involve casein micelles with intact $\kappa$-casein layer being attacked by chymosin, then micelles partially denuded of $\kappa$-casein and further extensively denuded micelles in the process of clotting (Fox et al., 2000, Mei-Li, 2002). However, all the methods reviewed have limitations for use in largescale milk coagulation property (MCP) determination. Comparison of cheeses made from raw milk with those made from micro filtered or pasteurised milk has shown that the raw milk flora plays an essential role in the development of the sensory characteristics of hard cheeses (Beresford, 2003).

The overall phenomenon of milk coagulation is dependent on the $\kappa$-casein fraction and other soluble components present in milk (Mei-Li, 2002). In the clotting process, the concentration of calcium has a major contribution in determining the overall renneting time of milk. The primary phase of rennet action is controlled by the status of $\kappa$-casein in the casein micelle. The secondary phase in milk coagulation is dependent on the concentration of calcium present in milk. (Damodaran et al., 2008). Several factors influence milk coagulation kinetics including the nature and concentration of the coagulation enzyme, temperature, acidity, calcium and protein concentrations of the milk (O’Callaghan et al., 2002).

The stability of rennin is determined by measuring decrease in clotting time between the temperature range $25-40^{\circ} \mathrm{C}$, and observing the minimum clotting time between $\mathrm{pH} 4$ and 6 . Instability is maximum at $\mathrm{pH}$ less than 3.5 and results in a loss of $35 \%$ of initial activity at $30^{\circ} \mathrm{C}$. Above $\mathrm{pH} 7$, rennin loses its milk clotting activity and undergoes configurational changes due to changes in viscosity and ultraviolet absorption (Mateo et al., 2009). Coagulation of milk happens when the casein micelles stick together. Casein micelles are hydrophobic and their natural tendency is toaggregate.In normal milk thisprocess is prevented by glucomacropeptide and negative charge on the micelles. Introducing chymosin to the cheese milk destabilizes the casein micelle in to two step reactions, the first of which is enzymatic (primary) and the second, non enzymatic (secondary). These two steps are separate but cannot be visually distinguished, only the appearance of curd signifies the completion of both steps (Fox et al., 2000).

Rennet alternatives may be necessary for reasons, such as vegetarianism, veganism or kosher lifestyles. It is not mandatory that commercial cheese makers to reveal whether the source of their rennet enzyme is artificially synthesized, is real rennet gleaned from a stomach, or is a non-rennet alternative. Alternatives that can achieve the same result as rennet include vinegar and lemon juice. Other options are to acquire "vegetable rennet" made from one of several plants like Cynara L. (Luisa et al., 2003), sunflower and albizia (Egito et al., 2006), thistle, nettle and mallow, or "microbial rennet" acquired from mold, mucor meihei (Hubble and Mann, 1984).

Microbial rennet from Bacillus amyloliquefaciens produce miniature cheddar type cheese result into improved texture, low raise in $\mathrm{pH}$ over $60 \mathrm{~d}$ of ripening, due to nitrogen content compared to calf rennet cheese (Zhigang et al., 2014). Genetically engineered rennet, which was never actually in the stomach of an animal but rather produced in a lab, is another possible option (Hubble and Mann, 1984).

Cheese can be made from fungus Rhizomucor miehei which is a common inhabitant of cow dung. Pure culture of the fungus was prepared. Further, the organism is grown in seed media as well as in production media for the production of rennet enzyme. The extract obtained from the filteration of production media was subjected to ammonium sulphate and acetone precipitations and centrifuged to obtain rennet in crude form. (Sai Manasa et al., 2012).

The objective of this study is to predict the clotting time of milk and the strength of rennet in terms of 
volume of milk to volume of rennet required for milk clotting activity and optimize the parameters temperature, $\mathrm{pH}$ and calcium chloride concentration for minimum clotting time through response surface method.

\section{MATERIALS AND METHODS}

Collection of raw material: The raw material, which is the abomasum, was collected from Abattoirs Enterprise which was not older than 15 days by selecting unweaned calves.

Preparation of abomasums: The abomasum was washed and the fat and veins were removed in order to ensure quality of the final product. The inflated abomasum was hung in a dry, well ventilated area. Drying will be complete in a month time and the abomasum sliced in to thin strips of $25 \mathrm{~mm}$ width, soaked in an easy to clean basin of stainless steel with a solution of sodium chloride and sodium benzoate solution of $6 \%$ and $0.1 \%$ concentration respectively (Libouga, 2004), in order to ensure the best yield of rennet in terms of clotting time. The soaking process was carried for 24 hours with water bath with thermostat maintained at a temperature ranging from 20 to $25^{\circ} \mathrm{C}$.

Treatment of the liquid: To eliminate the mucilage in suspension in the extract, the solution was reacidified with hydrochloride acid to a $\mathrm{pH}$ of 4.8 , and allowed to settle for two hours. The liquid was then filtered with distributed filters with Whatman filter paper No 42, completed within $1 \mathrm{~h}$.

Milk clotting activity of calf rennet: Clotting behavior of calf rennet was studied at different $\mathrm{pH}$ of the calf rennet $(4,5$ and 6$)$, temperature of milk $\left(30^{\circ} \mathrm{C}, 35^{\circ} \mathrm{C}\right.$, $40^{\circ} \mathrm{C}$ ), and addition of calcium chloride concentration in milk $(0.1,0.2,0.3 \mathrm{gm} / 500 \mathrm{ml})$.

Determination of strength (clotting activity): rennet strength is the number of volumes of coagulated milk clotted by one volume of rennet at specified time and temperature (Lambert, 1988). The strength of calf rennet was analyzed according to the method as described by Lambert (1988) as given in equation 1 .

$\mathrm{S}=2400 \times \mathrm{V} / \mathrm{t} \times \mathrm{V}$

Where, $\mathrm{S}$ is the strength of rennet under specified parameters, $\mathrm{V}$ is one volume of milk, $\mathrm{ml}, \mathrm{v}$ is one volume of rennet, $\mathrm{ml}$. and $\mathrm{t}$ is measured clotting time, $\mathrm{s}$.

17 different clotting times were obtained by varying the three factors at three levels (Table 1) to get a quadratic regression and robust optimization model. The data obtained from experiments, were used to find out the optimum point of the process parameters by using Box-Behnken Design in Response surface methodology.

Data analysis: Experimental designs nowadays have been regarded as one of the most favorable techniques in covering a large area of practical statistics and obtain unambiguous results with the least expense. According to Montgomery (2005), Response surface method (RSM) design help to quantify the relation- ships between one or more measured responses and the vital input factors. The most popular response surface methodologies are Central Composite, Box-Behnken designs.

Box-Behnken design is an efficient and creative threelevel composite design for fitting second-order response surfaces. It is an independent quadratic design. The methodology is based on the construction of balance designs which are rotatable and enable each factor level to be tested several times. Each factor or equally spaced values (coded as $-1,0$, and +1 ). In this design the treatment combinations are at the midpoints of edges of the cubical design region and at the center. Response surface methodology (RSM) was used to optimize clotting time using Box-Behnken design (Box and Behnken, 1960). The behavior of the system was explained by the following quadratic equation,

\section{$\mathrm{Y}=\beta_{0}+\beta_{\mathrm{i}} \mathrm{X}_{\mathrm{i}}+\beta_{\mathrm{ij}} \mathrm{X}_{\mathrm{i}} \mathrm{X}_{\mathrm{j}}+\beta_{\mathrm{ii}} \mathrm{X}_{\mathrm{i}}^{2}$}

Where $Y$ is the predicted response variable, $\beta_{0}$ is constant regression coefficient independent of the input variables, $\beta_{\mathrm{i}}$ is the coefficient based on individual input variable, $\beta_{\mathrm{ii}}$ is the coefficient square of the individual variables and $\beta_{\mathrm{ij}}$ is the coefficient of interactive variables taken two at a time and $\mathrm{X}_{\mathrm{i}}\left(\mathrm{A}=\mathrm{X}_{1}, \mathrm{~B}=\mathrm{X}_{2}, \mathrm{C}=\mathrm{X}_{3}\right)$ represent the independent variables in the form of coded values as shown in Table 3. Statistical software package Design-Expert ${ }^{\circledR}$ (Version 7, State-Ease, USA) was used to design and analyze the experiment. In this research, optimization of milk clotting activity of local calf rennet using design experiments by Box-Benhken

Table 1. Experimental design of the study.

\begin{tabular}{clccc}
\hline \multirow{2}{*}{ No. } & \multirow{2}{*}{ Processing factors } & \multicolumn{3}{c}{ Levels } \\
\cline { 3 - 5 } & & $\mathbf{1}$ & $\mathbf{2}$ & $\mathbf{3}$ \\
\hline 1 & Temperature $\left({ }^{\circ} \mathrm{C}\right)$ & 30 & 35 & 40 \\
2 & $\mathrm{pH}$ & 4 & 5 & 6 \\
3 & Calcium chloride & 0.1 & 0.2 & 0.3 \\
& $(\mathrm{gm} / 500 \mathrm{ml})$ & & & \\
\hline
\end{tabular}

Table 2. Design of experiments.

\begin{tabular}{|c|c|c|c|}
\hline $\begin{array}{l}\text { Experiment } \\
\text { No. }\end{array}$ & Temperature, ${ }^{\circ} \mathrm{C}$ & pH & $\begin{array}{lr}\mathrm{CaCl}_{2} & \text { Conc. } \\
\mathrm{gm} / & 500 \mathrm{ml} \\
\mathrm{milk} & \end{array}$ \\
\hline 1 & 30 & 4 & 0.1 \\
\hline 2 & 30 & 4 & 0.3 \\
\hline 3 & 30 & 5 & 0.2 \\
\hline 4 & 30 & 5 & 0.3 \\
\hline 5 & 30 & 6 & 0.1 \\
\hline 6 & 30 & 6 & 0.2 \\
\hline 7 & 35 & 4 & 0.1 \\
\hline 8 & 35 & 4 & 0.2 \\
\hline 9 & 35 & 5 & 0.3 \\
\hline 10 & 35 & 6 & 0.2 \\
\hline 11 & 35 & 6 & 0.3 \\
\hline 12 & 40 & 4 & 0.2 \\
\hline 13 & 40 & 4 & 0.3 \\
\hline 14 & 40 & 5 & 0.1 \\
\hline 15 & 40 & 5 & 0.2 \\
\hline 16 & 40 & 6 & 0.1 \\
\hline 17 & 40 & 6 & 0.3 \\
\hline
\end{tabular}


Table 3. Analysis of variance (ANOVA).

\begin{tabular}{llllll}
\hline Source & Sum of squares & df & Mean square & F value & p- value Prob $>$ F \\
\hline Model & $1.110 \mathrm{E}+005$ & 9 & 12332.56 & 71.34 & $<0.0001$ \\
$\mathrm{~A}-$ temprature & 50244.5 & 1 & 50244.5 & 290.66 & $<0.0001$ \\
$\mathrm{~B}-\mathrm{pH}$ & 21528.13 & 1 & 21528.13 & 124.54 & $<0.0001$ \\
$\mathrm{C}-\mathrm{CaCl}_{2}$ & 26565.13 & 1 & 26565.13 & 153.68 & $<0.0001$ \\
$\mathrm{AB}$ & 1122.25 & 1 & 1122.25 & 6.49 & $0.0382^{*}$ \\
$\mathrm{AC}$ & 4556.25 & 1 & 4556.25 & 26.30 & $0.0013^{*}$ \\
$\mathrm{BC}$ & 1849.00 & 1 & 1849.00 & 10.7 & $0.0137^{*}$ \\
$\mathrm{~A}^{2}$ & 99.04 & 1 & 99.04 & 0.57 & 0.4738 \\
$\mathrm{~B}^{2}$ & 873.09 & 1 & 873.09 & 5.05 & 0.0594 \\
$\mathrm{C}^{2}$ & 4020.25 & 1 & 4020.25 & 23.26 & $0.0019^{*}$ \\
Residuals & 1210.05 & 7 & 172.88 & & 0.1071 \\
Lack of fit & 907.25 & 3 & 302.42 & 3.99 & \\
Pure error & 302.80 & 4 & 75.70 & & \\
Cor total & $1.122 \mathrm{E}+005$ & 16 & & & \\
\hline
\end{tabular}

*indicate significance of the model $(\mathrm{P}<0.05)$.

Design was studied.

\section{RESULTS AND DISCUSSION}

Extraction of the rennet: Among the abomasums soaked with $10 \%, 15 \%$ and $20 \%$ of sodium chloride, the abomasums soaked with $15 \%$ concentration of sodium chloride showed a better clotting time. The rennet extracted from one abomasums of the local calf in this experiment was two liters.

Optimization of milk clotting time using calf rennet: Process optimization was carried out by conducting 17 experiments to identify the best combinations of the parameters which are involved in the clotting activity of the calf rennet (Table 2). The aim of this optimization was to get minimum clotting time, (s) of the milk. The parameters such as temperature of the milk (30, 35 and $\left.40^{\circ} \mathrm{C}\right), \mathrm{pH}$ of calf rennet $(4,5,6)$ and calcium concentration of milk $(0.1,0.2$ and $0.3 \mathrm{gm} / 500 \mathrm{ml})$ were selected (Table 1). Selection was made based on the stability of rennin, determined by measuring decrease in clotting time during $30^{\circ} \mathrm{C}-40^{\circ} \mathrm{C}$, and minimum clotting time between $\mathrm{pH} 4$ and 6 at calcium concentration of 0.1 to $0.3 \mathrm{gm} / 500 \mathrm{ml}$ of milk. Instability is maximum at $\mathrm{pH}$ less than 3.5 and resulted in a loss of $35 \%$ of initial activity at $30^{\circ} \mathrm{C}$. Above $\mathrm{pH} 7$, rennin loses its milk clotting activity and configurational

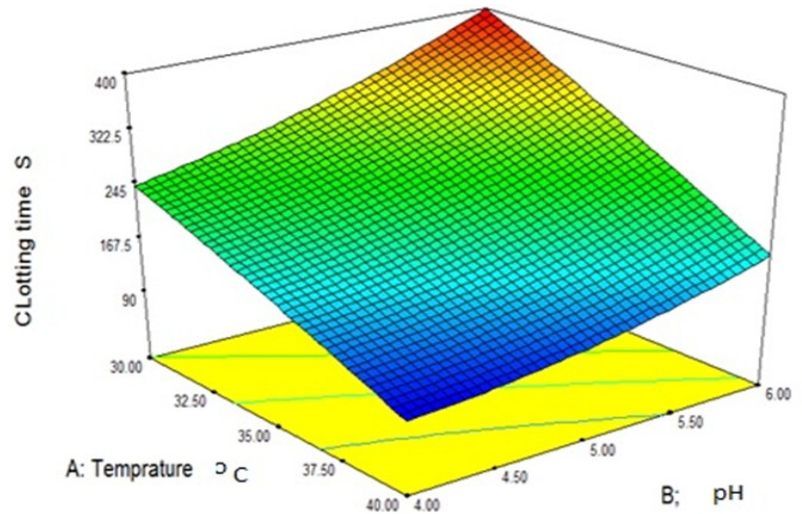

Fig. 1. Response surface plot for temperature and $\mathrm{pH}$. changes that take place due to changes in viscosity and ultraviolet absorption. Concentration of $\mathrm{CaCl}_{2}$ had great role in coagulation of milk (De Kruif, 1999). Besides, if the temperature exceeds $40^{\circ} \mathrm{C}$ the enzyme undergoes denaturation and loses its activity.

Analysis of variance: From ANOVA table (Table 3) it can be seen that the model (Equation 3 ) as fitted can explain $98.9 \%$ of the confidence could be used to predict milk clotting time, thus confirming the adequacy of the model. Clotting time depends on the three input variables, temperature, $\mathrm{pH}$ and concentration of $\mathrm{CaCl}_{2}$ significantly and the also depends strongly on the interactive variables taken two at a time and on quadratic term with $\mathrm{CaCl}_{2}$ concentration. Pure quadratic term on temperature and $\mathrm{pH}$ is not significant.

The lack of fit of the model was $p=0.1071$ which is not significant indicating that the model equations was adequate for predicting the response under any combination of values of the variables.

\section{Final equation in terms of actual factors:}

Clotting time $=+517.0250+0.9800 * \mathrm{~T}+68.12500 *$ $\mathrm{pH}-3099.50000$

* $\mathrm{CaCl}_{2}-3.35000 * \mathrm{~T} * \mathrm{pH}+67.50000 * \mathrm{~T} *$

$\mathrm{CaCl}_{2}-215.00000 * \mathrm{pH} * \mathrm{CaCl}_{2}+3090.00000 *\left(\mathrm{CaCl}_{2}\right)^{2}$

As depicted in equation, the temperature and $\mathrm{pH}$ had

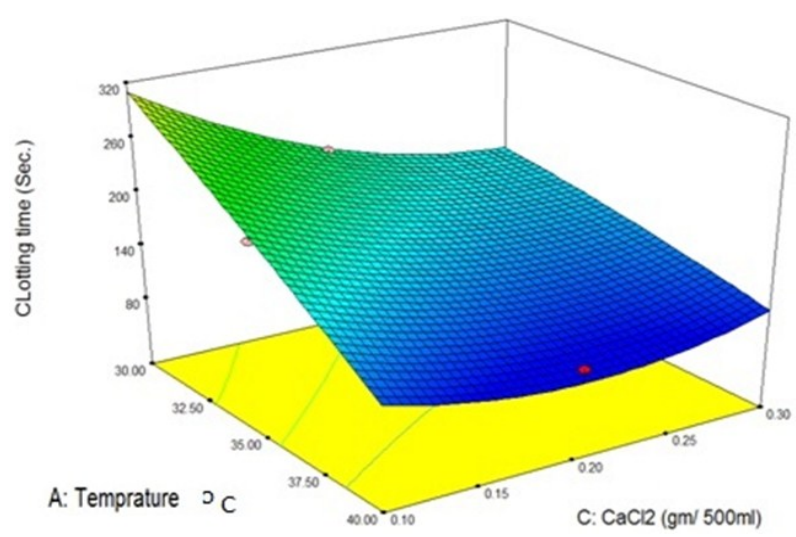

Fig. 2. Response surface plot for temperature and $\mathrm{CaCl}_{2}$. 


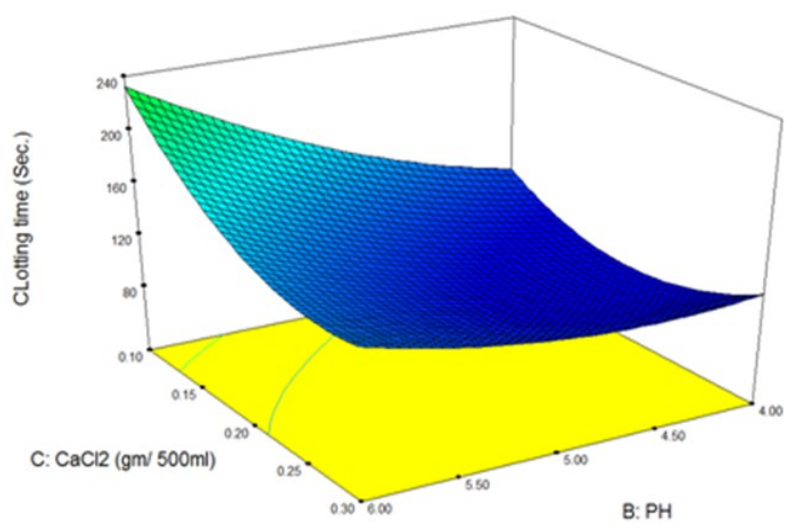

Fig. 3. Response surface plot for $\mathrm{CaCl}_{2}$ and $\mathrm{pH}$.

positive coefficients which indicate both factors had great role in milk clotting activity. In case of $\mathrm{CaCl}_{2}$, positive coefficient of quadratic term has less influence over negative coefficient of linear term for concentration less than unity which has inverse response. The interactive variable temperature and $\mathrm{CaCl}_{2}$ has positive coefficient and other two combination of interactive variables temperature, $\mathrm{pH}$ and $\mathrm{pH}, \mathrm{CaCl}_{2}$ has negative influence on clotting time. The insignificant terms are eliminated in the model equation 3 .

Analysis of process variables by response surface plots: From the surface plot (Fig. 1) it can be indicated that as the temperature increases the clotting time of the milk will be minimized. In addition, as the $\mathrm{pH}$ of the rennet decreased the minimum clotting time was achieved. It could be interpreted as, in an acidic environment rennin digest the water soluble milk protein casein into insoluble products. The activation of rennin occurs best in acidic conditions. It is generally accepted that clotting temperatures of approx. $35^{\circ} \mathrm{C}-40^{\circ} \mathrm{C}$ produce gels with the highest firmness (Luecy, 2002). The results of this study clearly showed that, although working in different temperature range, the gel firmness is affected to a large extent.

From the surface plot (Fig. 2) below, a decreasing clotting time observed with increasing of temperature. Though slight increment in concentration of $\mathrm{CaCl}_{2}$ showed minimum clotting time, as it goes beyond $0.2 \mathrm{gm} / 500 \mathrm{ml}$ of $\mathrm{CaCl}_{2}$ it showed slight increment in clotting time. It could be interpreted as in the clotting process the concentration of calcium has a major contribution in determining the overall renneting time of milk. The primary phase of rennet action is controlled by the status of $\kappa$ - casein in the casein micelle. The secondary phase in milk coagulation is dependent on the concentration of $\mathrm{Ca}^{+}$ion present in the milk (Hamano, 1995).

The profile below (Fig. 3) showed that the interaction between $\mathrm{pH}$ of the calf rennet and concentration of $\mathrm{CaCl}_{2}$ influenced by the $\mathrm{pH}$. Minimum clotting time of milk was observed during slight decreasing of $\mathrm{pH}$. However, in reverse to this increasing in concentration of the $\mathrm{CaCl}_{2}$ resulted in minimum clotting time. It could be interpreted as, at low $\mathrm{pH}$ the activation of rennet would be increased and higher concentration of $\mathrm{CaCl}_{2}$ resulted in the precipitation of milk protein which is casein.

For sufficiently aged rennet gels, Zoon et al. (1989) showed that firmness increased linearly on reducing $\mathrm{pH}$ from approx. 6 to 4 , but then decreased on further lowering of the $\mathrm{pH}$.

According to Box-Benhken design result using Design -Expert ${ }^{\circledR}$ v.7 software, the optimum temperature of milk $\left({ }^{\circ} \mathrm{C}\right), \mathrm{pH}$ of calf rennet and concentration of calcium chloride $(\mathrm{gm} / 500 \mathrm{ml})$ for minimum clotting time (s) was $39.13^{\circ} \mathrm{C}, 4.00$ and $0.21 \mathrm{gm} / 500 \mathrm{ml}$ respectively with minimum clotting time of $91.27 \mathrm{~s}$.

\section{Milk clotting activity of the experimental rennet}

The strength (milk clotting activity) was calculated based on the equation (Lambert 1988):

$\mathrm{S}=2400 \times \mathrm{V} / \mathrm{t} \times \mathrm{v}$

Where, S- strength of rennet under specified parameters.

V- One volume of milk, ml.

$\mathrm{v}$ - One volume of rennet, $\mathrm{ml}$.

t- Measured clotting time, $\mathrm{s}$.

Hence, $\quad \mathrm{S}=2400 * 500 \mathrm{ml} / 91.27 \mathrm{~s} * 1 \mathrm{ml}$

$$
\mathrm{S}=13,148
$$

The clotting activity of the experiment had become 1: 13,148 . This implies 13,148 volume of milk clotted by one volume of rennet.

Clotting activity of the liquid rennet observed in the present study was within the range of activity of liquid rennet reported by (Cakmaki and Boroúlu, 2004; Lambert, 1988) i.e. ranged from 5670 to 45450 .

\section{Conclusion}

From this study, it was observed that two liters of calf rennet was extracted from one calf abomasum using four different batches obtained by successive extraction. Its strength was calculated based on Lambert (1988), and it was found to be $1: 13,148$. This implies 13,148 volume of milk clotted by one volume of rennet. The calf rennet obtained had been optimized using design expert V-7 aimed to give minimum clotting time. Based on the result, minimum clotting time of $91.27 \mathrm{~s}$ was achieved at the optimum conditions of temperature $39.13^{\circ} \mathrm{C}$, concentration of calcium chloride $0.21 \mathrm{gm} / 500 \mathrm{ml}$ and $\mathrm{pH}$ of 4 . Hence, the optimum operating conditions must be kept to achieve minimum clotting time.

\section{ACKNOWLEDGEMENTS}

The authors wish to thank the Program Chair, Dean, School of Mechanical, Chemical and Materials Engineering, Adama Science and Technology University, Ethiopia for the facilities and cooperation for completing this study. 


\section{REFERENCES}

Bent Foltmann, Vibeke Barkholt Pendersen, Dorothy Kauffman and Grith Wybrandt, (1979). The primary structure of Calf chymosin, The Journal of Biological Chemistry, 254(17): 8447-8456.

Beresford, T.P., (2003). Non-starter lactic acid bacteria (NSLAB) and cheese quality, in Gerrit Smith, Dairy Processing: Improving Quality, 448-469.

Box GEP and Behnken DW (1960). Some new three level designs for the study of quantitative variables. Technometrics, 2: 455-75.

Cakmaki, S., and E. Boroúlu, (2004). Some Quality Characteristics of Commercial Liquid Rennet Samples. Turkish Journal ofVetenary and AnimalScience, 28: 501505.

Cassandro, M., A. Comin, M. Ojala, R. Dal Zotto, M. De Marchi, L. Gallo, P. Carnier, and G. Bittante. (2008). Genetic parameters of milk coagulation properties and their relationships with milk yield and quality traits in Italian Holstein cows, Journal of Dairy Science, 91: 371-376.

Damodaran, S., Parkin, K. L., Fennema, O. R. (2008). Fennema's Food Chemistry, $4^{\text {th }}$ ed., CRC Press, Taylor and Francis Gp, Boca Raton, FL.

De Kruif, C. G. (1999). Casein micelle interactions. International Dairy Journal, 9: 183-188.

Egito, A. S., Girardet, J. M., Laguna, L. E., Poirson C.,Molle D., Miclo, L.,Humbert, G., Gaillard, J. L. (2006). Milk clotting activity of enzyme extracts from sunflower and albizia seeds and specific hydrolysis of bovine k-casein, International Dairy Journal, 17:816825

Fox, P.F., T.P., Guinee, T. M. Cogan, and P. L. H. Mcsweeney, (2000). Fundamentals of Cheese Science, Aspen, Gaithersburg, MD. Fox, P.L.H. McSweeney, T.M. Cogan and T.P. Guinee (eds.), Elsevier Academic.

Green M. L, Angel S, Lowe P. A, Marston A. O, (1985). Cheddar cheese making with recombinant calf chymosin synthesized in Escherichia. Journal of Dairy Research, 52: 281

Hamano, K., Ishii, T., Ozawa, M., Sengers, J. V., and Krall, A. H. (1995). Physics Review Letter, 51: 1254.

Hubble J., Mann, P. (1984). Destabilisation of microbial rennet, Biotechnology Letters, 6(6):341 - 344.

Katarzyna Skrzypczak, Waldemar Gustaw, Dominik Szwajgier, Emilia Fornal, Adam Wasko (2017). $\square$ Casein as a source of short chain bioactive peptides generated by Lactobacillus helveticus, Journal of Food Science and Technology, 54(11): 3679 - 3688.

Lambert, J. C., (1988). Village milk processing, FAO, Animal production and health Division.

Luecy J.A.l (2002). Rennet coagulation of milk. In encyclopedia of dairy sciences. (Roginski,H.,Fuquay, J.,W., Fox P., F., ed.), Academic Press. 1: 286 - 293.

Libouga D. G. (2004). Edibility of cheese manufactured using Ongokea gore extract, Tropical Science, 44:180 183.

Luisa Bivar Roseiro, Manela Barbose, Jennifer M Ames,
Andrew R Wilbey (2003). Cheese making with vegetable coagulants - the use of Cynara L. for the production of ovine milk cheeses. International journal of Dairy Technology, 56(2): $76-85$.

Mateo, M. J., O'Callaghan, D. J., Everard, C. D., Fagan, C. C., Castillo, M., Payne, F. A. and O'Donnell, C. P. (2009). Influence of curd cutting programme and stirring speed on the prediction of syneresis indices in cheese-making using NIR light backscatter. Lebensm. Wiss. Technology, 950-955.

Moghaddam Sh. Khalil, M. Khaleghian, F. Naderi, M. Azin, M. Monajjem (2008).Purification and characterization of milk clotting enzyme produced by Rhizomucor Rmiehei, Journal of Physical and Theoretical chemistry of Islamic Azad University of Iran, 5(3): 149-154.

Mei-Li Chiang (2002). Influence of the structure of rennet induced gels on the cheesemaking process and cheese composition. (Master Thesis), Institute of Food, Nutrition and Human health, Massey University, Palmerston, North New Zealand.

Montgomery, D. (2005). Design and analysis of experiments. John Wiley \& Sons Inc., New York.

Moran J. (2005). Tropical dairy farming: feeding management for small holder dairy farmers in the humid tropics,Landlinks press, 312 .

NATIONAL DAIRY COUNCIL, (1992). Technical Profile Rennet. ETP1/92. National Dairy Council, London, :4

O'Callaghan, D. J., C. P. O'Donnell, and F. A. Payne. (2002). Review of systems for monitoring curd setting during cheesemaking. International Journal of Dairy Technology, 55: 65-74.

SailajaV., Ravanaiah, G. and Narasimha Murthy C. V. (2017). Antioxidant Property Gorojanum, International Journal of Engineering Technology Science and Research, ISSN 2394 - 3386, 4(2): 43-47.

SaiManasa J., Shalini N., N. Yamuna Venkata Lakshmi and Shailaja Raj M. (2012). Production of Cheese from Rennet enzyme using Rhizomucor michei isolated from cow dung, Helix, 3: 169-172.

Sengul Mustafa, Erkaya Tuba, Muhammet Derissoglue, Ogus Aydemir, Osman Gul (2014). Compositional, biochemical and textural changes during ripening of Tulum Cheese made with different coagulants, International Journal of Dairy Technology, 67(3): 373-383.

Visser, S., Slangen, C.J. and van Rooijen, P.J. (1987). Peptide substrates for chymosin (rennin). Interaction sites in $\kappa$-casein-related sequences located outside the (103-108) -hexapeptide region that fits into the enzyme's activesite cleft, Biochemical Journal, 244: 553-558.

R.J. Whitehurst and B.A. Law. (2002). Enzymes in Food Technology, Sheffield Academic Press Ltd, Sheffield, UK, 96.

Zhigang An, Xiaoling He, Weidong Gao, Wei Zhao, Weibing Zhang (2014). Characteristics of miniature cheddar type cheese made by microbial rennet from Bacillus amyloliquefaciens: A comparison with commercial calf rennet, Journal of Food Science, 79(2):M214 - M221.

Zoon, Girardot B. (1989). Milk protein analysis and cheese yield. Journal of Dairy Science,81: 125-134. 